\title{
PENGUASAAN KOMUNIKASI, DISIPLIN, DAN KERJA SAMA MELALUI PRAKTIK KERJA INDUSTRI BIDANG MANUFAKTUR OLEH SISWA KELAS XII TEKNIK PEMESINAN SMK NEGERI 3 YOGYAKARTA
}

\author{
Teguh Raharjo ${ }^{1}$, Putut Hargiyarto ${ }^{2}$ \\ ${ }^{1,2}$ Program Studi Pendidikan Teknik Mesin Fakultas Teknik Universitas Negeri Yogyakarta \\ Email: teguh.raharjo2015@student.uny.ac.id
}

\begin{abstract}
This study aims to determine the communication skills, discipline, and teamwork of students after carrying out industrial work practices in the manufacturing sectors, and to study the implementation of the industrial work practices. The studied subjects are the students of class XII in the engineering expertise program of SMK Negeri 3 Yogyakarta. This research is a combination research type with a sequential explanatory strategy model with quantitative and qualitative data. Data were collected using interviews and documentation. The sampling techniques used are purposive sampling and snowball sampling with a sample of 76 students and one internship supervisor. Data analysis techniques used quantitative descriptive statistics, data frequency distribution, analysis of variable indicators, and qualitative analysis of interview results. The results showed that students' communication ability was classified as "good" with an accomplishment score of 78\%, discipline was classified as "very good" with an achievement score of $85 \%$, and student teamwork was classified as "very good" with an implementation score of $82 \%$, and the implementation of industrial work practices was classified as "good" with a value of $83 \%$.
\end{abstract}

Keywords: industrial work practices, communication, discipline, and team work

\begin{abstract}
ABSTRAK
Penelitian ini bertujuan untuk mengetahui kemampuan komunikasi, disiplin, dan kerja sama siswa kelas XII program keahlian Teknik Pemesinan SMK Negeri 3 Yogyakarta setelah melaksanakan kegiatan praktik kerja industri (prakerin) pada bidang manufaktur serta mengetahui pelaksanaan praktik kerja industri. Jenis penelitian ini adalah penelitian kombinasi dengan model strategi eksplanatoris sekuensial yang memiliki data berupa kuantitatif dan kualitatif. Metode pengumpulan data menggunakan angket, wawancara, dan dokumentasi serta teknik sampling yang digunakan adalah sampling purposive dan snowball sampling dengan sampel sebanyak 76 siswa dan 1 guru pembimbing prakerin. Teknik analisis data menggunakan statistik deskriptif kuantitatif, distribusi frekuensi data, analisis indikator variabel, dan analisis kualitatif hasil wawancara. Hasil penelitian menunjukkan bahwa kemampuan komunikasi siswa tergolong baik dengan nilai keterlaksanaan sebesar 78\%, kemampuan disiplin tergolong sangat baik dengan nilai keterlaksanaan sebesar 85\%, dan kemampuan kerja sama siswa tergolong sangat baik dengan nilai keterlaksanaan sebesar $82 \%$, serta pelaksanaan praktik kerja industri tergolong baik/efektif dengan nilai keterlaksanaan sebesar 83\%.
\end{abstract}

Kata kunci: prakerin, komunikasi, disiplin, dan kerja sama

\section{PENDAHULUAN}

Mengingat bahwa persaingan pasar bebas dan pasar tenaga kerja yang semakin ketat, pemerintah menekankan pengembangan untuk mempersiapkan calon tenaga kerja yang ahli di bidangnya. Sekolah Menengah Kejuruan (SMK) merupakan jenjang pendidikan yang bertujuan untuk menghasilkan lulusan yang siap kerja dan siap bersaing 
menghadapi perkembangan-perkembangan teknologi. Suryanto (2013: 108) menyatakan kesiapan lulusan untuk memasuki dunia kerja melibatkan tiga faktor, yaitu fisiologis, hard skill, dan soft skill. Artinya, pendirian SMK dimaksudkan untuk menyiapkan kebutuhan tenaga kerja tingkat menengah yang siap kerja dengan bekal keterampilan yang cukup setelah mengikuti pendidikan dan latihan.

Berkembangnya teknologi dengan pesat memunculkan suatu perubahan zaman atau era. Perubahan zaman yang menjadi topik utama perbincangan dunia saat ini adalah berkembangnya Revolusi Industri 4.0. Ciri yang paling mendasar berkembangnya revolusi industri 4.0 adalah berkurangnya peran manusia secara fisik dalam berbagai aktivitas sehari-hari dan produksi pada dunia industri. Artinya peran manusia akan digantikan menggunakan teknologi-teknolgi yang canggih seperti mesin, robot, dan kecerdasan buatan lainnya. Wongso dalam (Sri Siswati, 2019: 266) menyatakan untuk dapat bertahan dalam revolusi industri 4.0, manusia harus memiliki tiga literasi utama yaitu literasi data, literasi teknologi, dan literasi manusia (human literacy). Literasi manusia yang diartikan disini adalah pemahaman untuk mengolah suatu informasi sesasama manusia (soft skills). Penguasaan soft skills adalah suatu kemampuan/keterampilan yang berhubungan dengan orang lain atau kecerdasan emosional, yang merujuk pada kemampuan berinteraksi secara nyaman dengan orang lain. Maka dari itu, agar dapat beradaptasi dengan perubahan yang diakibatkan revolusi industri 4.0 seseorang harus memiliki kemampuan yang tidak bisa dilakukan oleh mesin (Sri Siswati, 2019: 265). Berdasarkan hal tersebut dapat disimpulkan bahwa kemampuan soft skills pada revolusi industri 4.0 sangat dibutuhkan, dimana soft skills yang dimiliki tersebut hanya bisa dilakukan oleh manusia dan tidak bisa dilakukan oleh mesin, robot, atau kecerdasan buatan lainnya. Sebagai contoh kemampuan softskills yang berkaitan dengan pemecahan masalah atau kreativitas tidak dapat dilakukan oleh mesin, maka dari itu seseorang harus memiliki kemampuan tersebut dan atribut softskills lainnya untuk dapat bertahan pada revolusi industri 4.0.

Mengetahui bahwa lulusan SMK akan terjun ke dalam dunia industri atau dunia kerja, maka lulusan SMK juga dituntut untuk memiliki kemampuan softs kills yang sesuai atau dibutuhkan pada dunia kerja agar bertahan pada perubahan atau perkembangan revolusi industri 4.0. Atribut dari soft skills tersebut sangat bermacam-macam, mulai dari kemampuan berpikir kritis, memecahkan masalah, komunikatif, kreatif, tanggung jawab, disiplin, kerja sama, dan sebagainya. Berdasarkan berbagai macam atribut soft skills tersebut, maka minimal siswa dapat menguasai kemampuan atau atribut tersebut yang digunakan di era perkembangan teknologi.

Sesuai dengan berkembangnya revolusi industri 4.0 yang telah diuraikan, lulusan SMK harus memiliki kemampuan dimana kemampuan tersebut tidak dapat dilakukan oleh mesin, robot, dan kecerdasan buatan lainnya, salah satu kemampuan tersebut adalah kemampuan komunikasi. Komunikasi merupakan atribut kunci atau kemampuan penting untuk melakukan sebuah pekerjaan. Tanpa adanya komunikasi, suatu pekerjaan atau proses produksi tentunya tidak akan berjalan. Levy and Murnae dalam Sri Siswati (2019: 268), mengungkapkan bahwa tugastugas yang memerlukan keahlian berpikir dan keahlian komunikasi menjadi sangat penting bagi setiap orang di masa depan. Artinya, seberapapun nanti perubahan zaman tersebut, komunikasi tetap akan menjadi atribut penting untuk menjalankan tugas-tugas atau proses produksi pada dunia kerja atau dunia industri. Sebagai contoh, dengan terjadinya revolusi industri 4.0, untuk menjalankan berbagai macam robot/mesin/kecerdasan buatan lainnya pasti dibutuhkan kontak antar manusia untuk melakukan komunikasi seperti menjelaskan prosedur pengoperasiannya, menjelaskan halhal yang dilakukan saat pengoperasiannya, dan sebagainya. Maya pada penelitiannya (2020: 
75), juga mengungkapkan dengan adanya teknologi media komunikasi yang canggih dan berkembang saat ini seperti aplikasi media sosial dan digital lainnya, kemampuan komunikasi seperti tata krama, etika berkomunikasi, dan mengenali siapa yang diajak berkomunikasi, serta mengetahui apa yang dibicarakan sangat dibutuhkan agar penggunaan teknologi-teknologi yang canggih tersebut bisa sesuai dengan tujuannya dan tidak menimbulkan konflik atau permasalahan.

Atribut soft skills lainnya yang dituntut untuk dimiliki oleh lulusan SMK adalah kemampuan disiplin dan kemampuan kerja sama. Kemampuan disiplin dan kerja sama menjadi hal yang penting bagi dunia kerja/dunia industri untuk melakukan sebuah pekerjaan atapun proses-proses produksi lainnya. Selain kemampuan berkomunikasi, softskills yang dibutuhkan di dunia industri adalah kemampuan disiplin. Perkinson (2005: 15) dalam penelitiannya menyatakan bahwa dengan penerapan disiplin yang tinggi perusahaan dapat memperoleh keuntungan yang tinggi, karena dengan disiplin yang tinggi seseorang mampu meningkatkan efektivitas kerja. Hal itu mengartikan bahwa jika seseorang yang bekerja pada suatu industri memiliki kedisiplinan yang baik, maka setiap perilaku/sikap yang dilakukan akan menyesuaikan standar operasional yang telah berlaku pada duna industri tersebut, sehingga proses produktivitas atau pelaksanaan pekerjaan akan menjadi lebih baik atau efektif serta perusahaan atau dunia industri tersebut mendapat manfaat yang besar juga, sehingga tentu semua dunia industri akan mencari lulusan-lulusan atau sumber daya manusia (SDM) dengan kualitas disiplin yang baik.

Sri Siswati dalam penelitiannya (2019: 266), menyebutkan salah satu jenis literasi manusia agar bisa bertahan pada revolusi industri 4.0 adalah bekerja dalam tim. Seperti yang telah diuraikan di atas bahwa kemampuan yang dibutuhkan pada era revolusi industri 4.0 adalah kemampuan yang tidak dimiliki oleh mesin, robot, maupun kecerdasan buatan lainnya, salah satu nya adalah bekerja dalam tim atau kerja sama. Semua mesin, robot, atau kecerdasan buatan lainnya tidak akan bisa bekerja sama, karena yang akan bekerja sama adalah seseorang/karyawan/tenaga kerja yang menjalankan/mengoperasikan mesin-mesin ataupun teknologi tersebut. Jika suatu perusahaan atau dunia industri memiliki SDM dengan kemampuan kerja sama yang baik, maka hubungan kerja antar bagian atau unit kerja akan berjalan dengan lancar (Sri Wiranti, 2012: 64). Hal ini mengartikan bahwa suatu dunia industri atau dunia kerja memiliki berbagai macam bagian-bagian kerja dimana antar bagian tersebut dibutuhkan pemahaman antar tim, interaksi, dan bentuk kerja sama lainnya sehingga semua bagian/unit kerja/ unit bidang/unit produksi dapat melengkapi kekurangan/kesalahannya dan dunia industri tersebut dapat beroperasi dengan baik.

Livia (2018: 423) dalam hasil penelitiannya ke salah satu perusahaan di Indonesia menyatakan bahwa peranan dari kerja tim adalah membantu menyelesaikan setiap tugas atau permasalahan yang ada di dalam tim dalam lingkup perusahaan tersebut, sehingga hal itu dapat mengatasi jika ada kinerja karyawan yang produktivitasnya sedang menurun. Berdasarkan hal tersebut maka kemampuan kerja sama juga dapat digunakan sebagai penyelesaian masalah di dalam suatu dunia industri, sehingga hambatan-hambatan yang terjadi pada industri tersebut bisa diselesaikan dan industri bisa berjalan dengan lancar. Berdasarkan uraianuraian di atas tersebut dapat disimpulkan bahwa lulusan SMK yang akan bekerja pada dunia industri agar dapat bertahan pada era revolusi industri 4.0 maupun perkembangan teknologi lainnya, dituntut untuk memiliki kemampuan-kemampuan softskills seperti kemampuan komunikasi, disiplin, dan kerja sama.

Kemampuan soft skills seperti komunikasi, disiplin, dan kerja sama tentunya harus disesuaikan dengan apa yang dibutuhkan oleh dunia kerja atau dunia industri. Langkah 
yang dilakukan dari lembaga pendidikan terutama SMK untuk menyesuaikan kebutuhan dunia industri adalah link and match. Link and match adalah suatu kolaborasi yang melibatkan kedua belah pihak seperti SMK dan dunia industri, agar kedua pihak tersebut bisa saling menyesuaikan apa yang dibutuhkan dan apa yang perlu dikembangkan. Suroto dan Nguyen Tien Hung (2018: 46) menyatakan bahwa salah satu bentuk dari kolaborasi SMK dan dunia Industri adalah dengan melaksanakan Praktik Kerja Industri (Prakerin). Dasar praktik kerja industri adalah pendidikan kejuruan yang mempersiapkan siswa agar dapat bekerja dibidang tertentu, dengan kata lain SMK dituntut untuk terus berkembang seiring dengan tuntutan peningkatan dunia kerja. Implementasi dari konsep praktik kerja industri ini adalah dengan menerjunkan siswanya untuk melakukan praktek industri di dunia usaha/industri.

Praktik Kerja Industri dapat membentuk kemampuan-kemampuan siswa SMK sebagai calon lulusan yang dibutuhkan oleh dunia industri. Penelitian yang dilakukan oleh Zamzam (2012: 406) menyatakan bahwa Praktik Kerja Industri mempengaruhi pembentukan kesiapan kerja siswa dengan sumbangan variabel sebesar 40,2\%. Kemudian penelitian dari Stevani (2015: 60) juga menyatakan bahwa Praktik Kerja Industri memiliki pengaruh yang signifikan terhadap kesiapan kerja siswa. Uraian tersebut menyatakan bahwa pembentukan kesiapan kerja siswa dapat dilakukan melalui kegiatan Praktik Kerja Industri. Kesiapan kerja sendiri merupakan suatu kondisi dimana siswa sudah mampu untuk terjun atau masuk ke dalam dunia kerja/dunia industri. Brady dalam Ajeng (2017: 18) menyatakan bahwa aspek yang meliputi kesiapan kerja adalah kemampuan komunikasi, adanya sikap/perilaku/sifat tanggung jawab, memiliki fleksibilitas, memiliki pandangan terhadap diri, dan kesehatan/keselamatan. Nadia (2018: 7), menyatakan salah satu aspek yang meliputi kesiapan kerja adalah kemampuan berkomunikasi. Nur Cahyono pada penelitiannya (2015: 195), mengungkapkan kesiapan kerja yang dapat dibentuk melalui Praktik Kerja Industri adalah kemampuan disiplin, kerja sama, inisiatif, kreativitas, keterampilan, tanggung jawab, dan kepemimpinan. Penelitian dari Siti Mariah dan Machmud Sugandi (2010: 15) menyatakan bahwa kegiatan Praktik Kerja Industri adalah salah satu metode untuk mengembangkan kemampuan softskills siswa sejak dini. Sedangkan Adriyati (2013: 59) juga menyatakan bahwa Praktik Kerja Industri memiliki pengaruh positif dengan pembentukan softskills siswa SMK. Berdasarkan hal tersebut dapat disimpulkan bahwa kegiatan Praktik Kerja Industri dapat membentuk suatu kesiapan kerja atau kemampuan yang meliputi banyak aspek/atribut softskills, mulai dari kemampuan komunikasi, kemampuan disiplin, kemampuan kerja sama, kreativitas, inisiatif, keterampilan bidang, dan sebagainya. Karena keterbatasan waktu dan ruang dalam penelitian, maka peneliti akan mengkaji atau meneliti beberapa kemampuan atau softskills yang dapat dibentuk melalui kegiatan prakerin seperti yang telah diuraikan diatas, kemampuan tersebut adalah Kemampuan Komunikasi, Kemampuan Disiplin, dan Kemampuan Kerja Sama.

Berdasarkan hal tersebut, kemudian peneliti melakukan sebuah penelitian/pengkajian terkait kemampuan komunikasi, disiplin, dan kerja sama dari siswa-siswa yang telah melaksanakan praktik kerja industri. Peneliti juga meneliti seberapa besar efektivitas pelaksanaan praktik kerja industri tersebut. Berdasarkan observasi awal di lapangan yaitu SMK N 3 Yogyakarta khususnya program keahlian teknik pemesinan, kemampuan komunikasi, disiplin, dan kerja sama siswa masih kurang. Setelah ditinjau lebih lanjut kurangnya kemampuan kemampuan komunikasi, disiplin, dan kerja sama tersebut ternyata dilakukan oleh siswa yang belum melaksanakan kegiatan praktik kerja industri. Berdasarakan hal tersebut juga 
munculah sebuah pertanyaan yang peneliti rumuskan yaitu bagaimana dengan kemampuan komunikasi, disiplin, dan kerja sama oleh siswa yang telah melaksanakan praktik kerja industri bidang manufaktur, kemudian bagaimana efektivitas pelaksanaan praktik kerja industri tersebut.

\section{METODE}

Jenis penelitian yang digunakan oleh peneliti adalah metode kombinasi (mixed methods). Menurut Sugiyono (2011: 204), metode penelitian kombinasi (mixed methods) adalah metode penelitian yang mengkombinasikan atau menggabungkan antara metode kuantitatif dan metode kualitatif untuk digunakan secara bersama-sama dalam suatu kegiatan penelitian sehingga diperoleh data yang lebih komprehensif, valid, reliabel, dan objektif. Berdasarkan penjelasan tersebut dapat diartikan bahwa metode penelitian kombinasi (mixed methods) adalah metode penelitian yang menggunakan dua metode yaitu metode kuantitatif dan metode kualitatif sehingga diperoleh data yang lebih mendalam dan bermakna.

Model (design) pada metode penelitian kombinasi ini menggunakan model strategi eksplanatoris sekuensial (sequential explanatory design). Menurut Cresswell dalam Sugiyono (2011: 409), strategi eksplanatoris sekuensial ini dilakukan dengan melakukan pengumpulan data dan analisis kuantitatif pada tahap pertama, dan diikuti dengan pengumpulan dan analisis data kualitatif pada tahap kedua, guna memperkuat hasil penelitian kuantitatif yang dilakukan pada tahap pertama. Artinya pada penelitian kombinasi (mixed methods) dengan model strategi eksplanatoris sekuensial (sequential explanatory design) tersebut, peneliti mengambil data kuantitatif terlebih dahulu dan menganalisis data tersebut, kemudian peneliti melanjutkan pengambilan data kualitatif dan menganalisis data tersebut serta pada tahap terakhir peneliti menyajikan data-data yang diambil tersebut sebagai bentuk hasil penelitian.

Penelitian dilaksanakan di SMK N 3 Yogyakarta Jl. R.W. Monginsidi No. 2, Cokrodiningratan, Kec. Jetis, Kota Yogyakarta, Daerah Istimewa Yogyakarta. Waktu penelitian terbagi menjadi 3 yaitu observasi awal atau pencarian masalah untuk diteliti dilaksanakan pada SeptemberNovember 2018, pembuatan proposal penelitian dilaksanakan pada AgustusDesember 2019, dan pengumpulan data penelitian yang dilaksanakan pada tanggal 13 Februari-13 Maret 2020.

Penelitian kombinasi ini menggunakan populasi dan sampel. Populasi merupakan keseluruhan subyek penelitian dalam suatu wilayah. Menurut Suharsimi Arikunto (2010: 173), populasi adalah keseluruhan subyek penelitian. Apabila seseorang ingin meneliti semua elemen yang ada dalam wilayah penelitian, maka penelitiannya merupakan penelitian populasi. Artinya dalam hal ini populasi penelitian adalah seluruh siswa kelas XII program keahlian teknik pemesinan SMK Negeri 3 Yogyakarta yang telah melaksanakan kegiatan praktik kerja industri dan guru pembimbing dari kegiatan prakerin tersebut.

Menurut Sugiyono (2010: 118), sampel adalah bagian dari jumlah dan karateristik populasi tersebut sehingga untuk melakukan pengambilan sampel harus dilakukan dengan benar agar sampel yang diambil bisa mewakili (representatif) dari populasi tersebut. Berdasarkan hal tersebut peneliti mengambil sampel dengan menggunakan teknik purposive sampling dan snowball sampling. Purposive sampling adalah cara pengambilan sampel dengan berdasarkan pertimbangan tertentu seperti keterbatasan waktu, tenaga, dan dana sehingga tidak dapat mengambil sampel yang besar dan jauh (Suharsimi Arikunto, 2010: 183). Sedangkan Snowball sampling menurut Sugiyono (2010: 125) adalah pengambilan sampel dari yang mula-mula jumlahnya kecil kemudian bertambah. Berdasarkan hal tersebut peneliti mengambil sampel dengan Purposive 
Sampling sebanyak 76 siswa dengan pertimbangan yaitu siswa melakukan praktik kerja industri pada bidang manufaktur sehingga sesuai dengan program keahlian yang dipelajari di SMK. Peneliti kemudian menggunakan snowball sampling dengan menambah 1 guru SMK sebagai pembimbing praktik kerja industri yang digunakan untuk mengambil data kualitatif guna mendukung data kuantitatif ditahap awal.

Prosedur atau langkah-langkah dalam penelitian ini dijelaskan sebagai berikut. (1) Peneliti terjun ke SMK untuk mengambil data penguasaan komunikasi, disiplin, dan kerja sama terhadap siswa yang telah melaksanakan kegiatan praktik kerja industri pada bidang manufaktur melalui angket/kuisioner kemudian menganalisis data tersebut. (2) Peneliti mengambil data nilai kegiatan praktik kerja industri pada bidang manufaktur melalui dokumentasi dan menganalisis data tersebut. (3) Peneliti mengambil 2 siswa yang memiliki skor tertinggi dan skor terendah berdasarkan data angket/kuisioner serta 1 guru pembimbing kegiatan Prakerin untuk dilakukan wawawancara sehingga didapatkan data kualitatif. (4) Peneliti mengolah/menganalisis/mengkaitkan data kuantitatif dan kualitatif yang telah didapatkan untuk kemudian disajikan sebagai hasil penelitian.

Metode pengumpulan data yang digunakan adalah angket, dokumentasi, dan wawancara. Angket/kuesioner merupakan teknik pengumpulan data yang dilakukan dengan cara memberi seperangakat pertanyaan atau pernyataan tertulis kepada responden untuk dijawabnya (Sugiyono, 2010: 199). Angket/kuisioner tersebut digunakan untuk mengambil data kuantitatif terkait kemampuan komunikasi, disiplin, dan kerja sama siswa setelah melaksanakan kegiatan prakerin.

Menurut Sugiyono, 2010: 329, dokumentasi merupakan teknik pengambilan data melalui dokumen-dokumen baik itu tertulis atau tidak tertulis dari sebuah peristiwa yang sudah terlaksana. Kegiatan praktik kerja industri SMK N 3 Yogyakarta telah terlaksana dan nilai dari kegiatan prakerin itu sendiri sudah tercatat, sehingga teknik yang peneliti gunakan untuk mengambil nilai prakerin siswa tersebut adalah teknik dokumentasi. Nilai prakerin yang berupa data kuantitatif tersebut digunakan untuk mengukur keterlaksanaan kegiatan praktik kerja industri bidang manufaktur yang dilakukan oleh siswa teknik pemesinan SMK N 3 Yogyakarta.

Wawancara/interview adalah merupakan pertemuan dua orang untuk bertukar informasi dan ide melalui tanya jawab, sehingga dapat dikonstruksikan makna dalam suatu topik tertentu (Esteberg dalam Sugiyono, 2010: 319). Metode ini digunakan untuk mengambil data kualitatif guna mendalami data kuantitatif yang telah didapat sebelumnya melaalui angket/kuisioner, sehingga data yang akan dianalisis lebih mendalam dan bermakna. Berdasarkan yang telah dijelaskan pada model penelitian, maka instrumen penelitian yang digunakan dalam penelitian ini adalah angket/kuisioner, pedoman dokumentasi, dan pedoman wawancara. Tahap awal peneliti akan mengambil data kuantitatif yaitu kemampuan komunikasi, disiplin, dan kerja sama melalui teknik angket/kuisioner. Peneliti kemudian mengambil data kuantitatif yaitu nilai hasil prakerin menggunakan teknik dokumentasi. Setelah data kuantitatif dianalisis, peneliti mengambil data kualitatif dengan metode wawancara untuk mendukung data kuantitatif yang didapat ditahap awal.

Teknik analisis data yang digunakan dalam penelitian ini yaitu: (1) statistik deskriptif, (2) distribusi frekuensi, (3) analisis indikator variabel, (4) analisis hasil wawancara.

Analisis statistik ini digunakan untuk mendiskripsikan hasil penelitian secara jelas dan ringkas. Setelah peneliti mendapatkan skor total dari pengisian angket/kuisioner, kemudian peneliti akan mengkonversikan skor tersebut menjadi nilai atau ketercapaian. Peneliti menggunakan acuan dari Suharsimi 
Arikunto dalam Natsir Hendra (2011 :53) yaitu dengan rumus sebagai berikut:

$$
\text { Pencapaian }=\frac{\text { Skor Riil }}{\text { Skor Ideal }} \times 100 \%
$$

Tabel 1. Interpretasi Nilai/Skor Kemampuan

\begin{tabular}{cc}
\hline Skor (\%) & Keterangan \\
\hline $0-20$ & Sangat Kurang \\
$21-40$ & Kurang \\
$41-60$ & Cukup \\
$61-80$ & Baik \\
$81-100$ & Sangat Baik \\
\hline
\end{tabular}

Skor riil adalah skor yang didapat siswa, dan skor ideal adalah skor maksimal yang bisa diperoleh dari suatu butir soal. Peneliti menggunakan bantuan program dari IBM SPSS for Statistic version 26.0 for Windows dan Microsoft Excel 2013 untuk menganalisis data kuantitatif dari hasil penelitian yaitu data dari angket dan data dokumentasi nilai praktik kerja industri. Adapun komponen yang akan dianalisis atau dicari dalam data tersebut adalah mean, modus, median, Std.deviasi, Skor maksimum, Skor minimum.

Distribusi frekuensi data berfungsi untuk menyajikan data dengan jumlah yang cukup banyak. Ketika data tersebut dibaca, data bisa lebih efisien dan komunikatif (Sugiyono, 2010: 32). Berdasarkan distribusi frekuensi data, peneliti kemudian menginterpretasikan nilai tersebut kedalam suatu kategori menurut acuan dari Suharsimi Arikunto dalam Natsir Hendra (2011: 53) pada Tabel 1.

Analisis indikator variabel dilakukan dengan mendiskripsikan nilai atau ketercapaian dari indikator/faktor pembentuk kemampuan komunikasi, kemampuan disiplin, dan kemampuan kerja sama kemudian menginterpretasikan indikator tersebut menggunakan acuan dari kajian teori. Butir soal dalam indikator variabel yang diikutsertakan dalam kategori ketercapaian ini adalah butir soal yang sudah dinyatakan valid. Peneliti pada analisis ini menggunakan acuan yang sama yaitu dari Suharsimi Arikunto dalam Natsir Hendra (2011 :53) yang dapat dilihat pada Tabel 1, Sedangkan untuk variabel praktik kerja industri peneliti menggunakan acuan yang sudah terdapat buku pedoman praktik kerja industri SMK N 3 Yogyakarta (2019: 3) pada Tabel 2.

Tabel 2. Interpretasi Nilai/Skor Prakerin

\begin{tabular}{|c|c|c|}
\hline Nilai & Keterangan & Kategori \\
\hline $86-100$ & $\begin{array}{c}\text { Mampu } \\
\text { Menyelesaikan } \geq \\
\text { 75\% Pekerjaan }\end{array}$ & $\begin{array}{c}\text { Sangat } \\
\text { Baik }\end{array}$ \\
\hline 80-85 & $\begin{array}{c}\text { Mampu } \\
\text { Menyelesaikan } \geq \\
\text { 50\% Pekerjaan }\end{array}$ & Baik \\
\hline 75-79 & $\begin{array}{c}\text { Mampu } \\
\text { Menyelesaikan } \geq \\
\text { 25\% Pekerjaan }\end{array}$ & Cukup \\
\hline$>75$ & $\begin{array}{c}\text { Mampu } \\
\text { Menyelesaikan < } \\
\text { 25\% Pekerjaan }\end{array}$ & Kurang \\
\hline
\end{tabular}

Analisis wawancara dilakukan dengan beberapa tahap. Tahap pertama pengumpulan data yaitu dengan cara tanya jawab antara peneliti dengan narasumber yaitu dua siswa yang telah melaksanakan praktik kerja industri dan satu guru pembimbing prakerin mengenai kemampuan komunikasi, disiplin, dan kerja sama, serta pelaksanaan praktik kerja industri. Tahap berikutnya adalah pemilihan data dengan cara menentukan sejumlah data kualitatif dari hasil wawancara yang sesuai dengan fokus penelitian dan kajian teori yaitu tentang penguasaan kemampuan komunikasi, disiplin, dan kerja sama siswa melalui kegiatan praktik kerja industri. Tahap terakhir adalah penyajian dimana peneliti menyajikan analisis hasil wawancara kedalam sebuah kalimat atau paragraf untuk mendukung data kuantitatif yang sudah diperoleh dan dianalisis serta dikaitkan pada kajian-kajian teori.

\section{HASIL DAN PEMBAHASAN}

Penguasaan kemampuan komunikasi siswa setelah melaksanakan kegiatan praktik kerja industri tergolong ke dalam kategori Baik. Hal tersebut dibuktikan dengan hasil analisis statistik deskriptif pada Tabel 3 . Berdasarkan tabel tersebut rata-rata nilai/skor kemampuan komunikasi adalah $78 \%$ dan jika 
diinterpretasikan melalui acuan dari Suharsimi Arikunto dalam Natsir Hendra (2011 :53), maka kemampuan komunikasi tersebut tergolong kedalam kategori baik.

Tabel 3. Statistik Deskriptif Komunikasi

\begin{tabular}{lc}
\hline \multicolumn{1}{c}{ Deskripsi Data } & Nilai \\
\hline Jumlah (N) & 76 \\
Mean & 78 \\
Median & 79 \\
Modus & 79 \\
Std. Deviasi & 7,81 \\
Skor Maksimum & 100 \\
Skor Minimum & 63 \\
\hline
\end{tabular}

Data nilai/skor yang lebih detail/rinci atau untuk melihat presentase jumlah siswa dan kategori nilai/skor tersebut dapat dilihat pada Gambar 1. Berdasarkan gambar pie chart tersebut dapat dijelaskan bahwa 38\% siswa yang telah melaksanakan praktik kerja industri tergolong ke dalam kategori sangat baik dan 62\% siswa tergolong ke dalam kategori baik.

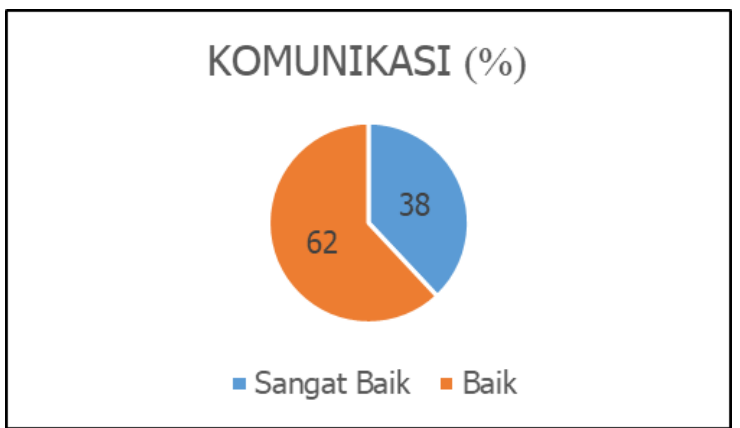

Gambar 1. Persentase Nilai Komunikasi Siswa

Melihat dari analisis indikator/faktorfaktor pembentuk kemampuan komunikasi dan diinterpretasikan dengan acuan dari Suharsimi Arikunto dalam Natsir Hendra (2011: 53) pada Tabel 1, maka didapatkan hasil pada Gambar 2. Berdasarkan hasil analisis skor/nilai indikator penguasaan komunikasi siswa kelas XII teknik pemesinan SMK N 3 Yogyakarta melalui praktik kerja industri dapat diketahui nilai/skor tertinggi tertinggi terletak pada indikator nomor 1 yaitu mengenali lawan bicara dengan nilai/skor 86\% dan tergolong kategori sangat baik. Nilai/skor dengan kategori cukup terletak pada indikator nomor
10 dan 11 yaitu menggunakan media yang tepat dan menguasai topik pembicaraan dengan nilai $60 \%$ dan $59 \%$.

Tabel 4. Indikator Kemampuan Komunikasi

\begin{tabular}{|c|c|}
\hline $\begin{array}{l}\text { Nomor } \\
\text { Indikator }\end{array}$ & Nama Indikator \\
\hline 1 & Mengenali Lawan Bicara \\
\hline 2 & $\begin{array}{l}\text { Menunjukkan Kemampuan } \\
\text { Non Verbal }\end{array}$ \\
\hline 3 & $\begin{array}{l}\text { Memilih Tata Bahasa yang } \\
\text { Baik }\end{array}$ \\
\hline 4 & $\begin{array}{l}\text { Pembicaraan Jelas dan } \\
\text { Dimengerti }\end{array}$ \\
\hline 5 & $\begin{array}{l}\text { Terdapat Informasi yang } \\
\text { Disampaikan }\end{array}$ \\
\hline 6 & $\begin{array}{l}\text { Saling Menghargai Lawan } \\
\text { Bicara }\end{array}$ \\
\hline 7 & $\begin{array}{l}\text { Memahami Situasi saat } \\
\text { Berkomunikasi }\end{array}$ \\
\hline 8 & Percaya Diri \\
\hline 9 & Bersikap Ramah \\
\hline 10 & Memilih Media yang Tepat \\
\hline 11 & $\begin{array}{ll}\text { Menguasai } & \text { Topik } \\
\text { Pembicaraan } & \end{array}$ \\
\hline
\end{tabular}

Berdasarkan indikator pada Tabel 4, dapat dilihat hasil analisisnya sebagaimana disampaikan dalam Gambar 2.

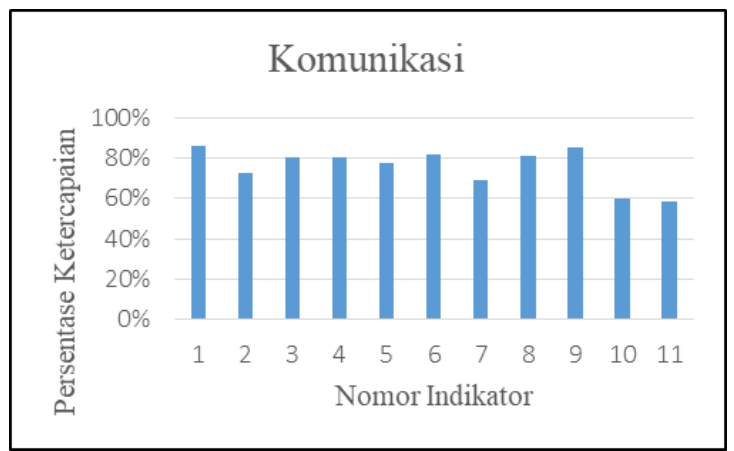

Gambar 2. Analisis Indikator Komunikasi

Berdasarkan uraian deskripsi data diatas dapat disimpulkan kemampuan komunikasi siswa kelas XII teknik pemesinan SMK N 3 Yogyakarta setelah praktik kerja industri tergolong Baik. Hal tersebut dikarenakan sebagian besar faktor-faktor pembentuk komunikasi dijalankan dengan baik/efektif saat kegiatan prakerin. Kemampuan komunikasi yang baik dan terbentuk saat kegiatan praktik 
kerja industri juga dinyatakan dalam hasil wawancara siswa, dimana siswa menyebutkan bahwa pembentukan kemampuan komunikasi saat praktik kerja industri adalah saat siswa diminta untuk menjelaskan sesuatu tentang pekerjaan seperti gambar kerja, mind mapping, prosedur pekerjaan, dan sebagainya kepada karyawan maupun kepada unit/lini lain pada industri tersebut. Hal tersebut sesuai dengan teori dari Brady dalam Ajeng (2017: 18), dimana praktik kerja industri dapat membentuk kesiapan kerja dimana salah satu aspek tersebut adalah kemampuan komunikasi. Tuntutan dari dunia industri dimana lulusan SMK harus memiliki kemampuan komunikasi yang baik juga menjadi faktor agar siswa memiliki atau memenuhi kemampuan komunikasi tersebut.

Hal tersebut berkaitan dengan hasil wawancara dari guru yang menyatakan bahwa sebagian besar industri yang telah menguasai IT dan digitalisasi akan membutuhkan SDM dengan kemampuan komunikasi yang baik dimana hal tersebut seperti pada teori penelitian dari Levy and Murnae dalam Sri Siswati (2019: 268), bahwa seberapapun perkembangan teknologi pada bidang industri kemampuan keahlian berpikir dan keahlian komunikasi tetap akan menjadi kemampuan yang penting dan harus dimiliki.

Penguasaan kemampuan disiplin siswa setelah melaksanakan kegiatan praktik kerja industri tergolong dalam kategori Sangat Baik. Hal tersebut dibuktikan dengan hasil analisis statistik deskriptif pada Tabel 5. Berdasarkan tabel tersebut rata-rata nilai/skor kemampuan disiplin adalah $85 \%$ dan jika diinterpretasikan melalui acuan dari Suharsimi Arikunto dalam Natsir Hendra (2011 :53), maka kemampuan kerja sama tersebut tergolong kedalam kategori sangat baik. Data nilai/skor yang lebih detail/rinci atau untuk melihat presentase jumlah siswa dan kategori nilai/skor tersebut dapat dilihat pada Gambar 3. Berdasarkan data tersebut dapat dilihat bahwa kemampuan disiplin siswa kelas XII teknik pemesinan SMK N 3 Yogyakarta setelah melaksanakan prakerin tergolong dalam kategori sangat baik $57 \%$, baik 38\%, dan cukup $4 \%$.

Tabel 5. Statistik Deskriptif Disiplin

\begin{tabular}{lc}
\hline Deskripsi Data & Nilai \\
\hline Jumlah (N) & 76 \\
Mean & 85 \\
Median & 87 \\
Modus & 93 \\
Std. Deviasi & 10,94 \\
Skor & 100 \\
Maksimum & \\
Skor Minimum & 57 \\
\hline
\end{tabular}

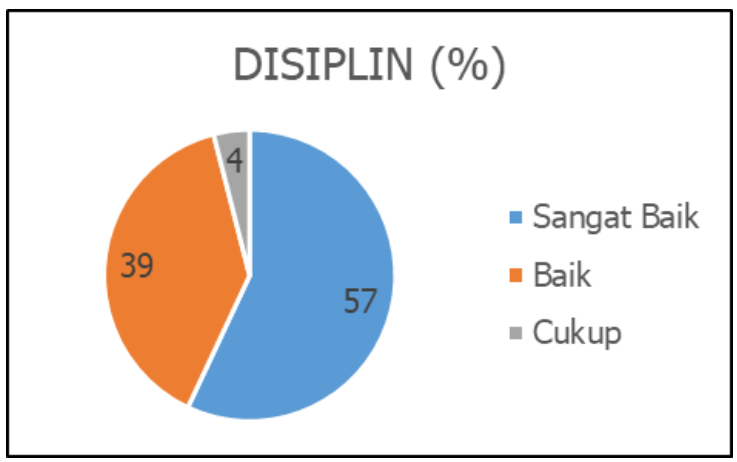

Gambar 3. Persentase Nilai Displin Siswa

Melihat dari analisis indikator/faktorfaktor pembentuk kemampuan disiplin dan diinterpretasikan dengan acuan dari Suharsimi Arikunto dalam Natsir Hendra (2011: 53) pada Tabel 1, maka didapatkan hasil pada Gambar 4. Berdasarkan hasil analisis skor/nilai indikator penguasaan disiplin siswa kelas XII teknik pemesinan SMK N 3 Yogyakarta melalui kegiatan praktik kerja industri dapat diketahui semua indikator dari kemampuan disiplin tergolong dalam kategori Sangat Baik. Nilai/skor tertinggi tertinggi terletak pada indikator nomor 5 yaitu Disiplin Sosial dengan nilai/skor 91\%. Nilai/skor terendah terletak pada indikator nomor 4 yaitu Disiplin Waktu dengan nilai/skor $81 \%$. 
Tabel 6. Indikator Kemampuan Disiplin

\begin{tabular}{cl}
\hline $\begin{array}{c}\text { Nomor } \\
\text { Indikator }\end{array}$ & \multicolumn{1}{c}{ Nama Indikator } \\
\hline 1 & Disiplin Diri \\
2 & Disiplin Belajar \\
3 & Disiplin Pekerjaan \\
4 & Disiplin Waktu \\
5 & Disiplin Sosial \\
6 & Disiplin Peraturan \\
7 & Disiplin Tata Krama \\
\hline
\end{tabular}

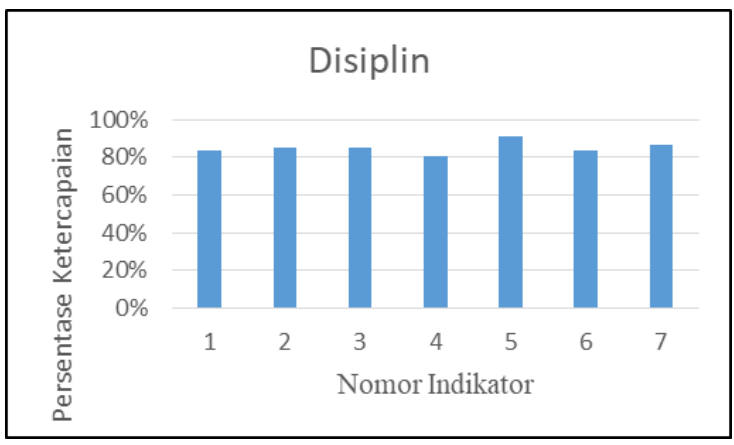

Gambar 4. Analisis Indikator Disiplin

Berdasarkan uraian tersebut dapat disimpulkan kemampuan disiplin siswa kelas XII teknik pemesinan SMK N 3 Yogyakarta setelah praktik kerja industri tergolong sangat baik. Hal yang mempengaruhi kemampuan disiplin yang tinggi adalah faktor-faktor pembentuk disiplin dijalankan dengan baik/efektif saat kegiatan prakerin. Hasil wawancara dari narasumber siswa menyatakan bahwa pembentukan kemampuan disiplin melalui kegiatan praktik kerja industri adalah job/pekerjaan/produk yang dikerjakan tidak hanya dituntut pada kualitasnya tetapi dituntut dalam ketepatan waktu penyelesaiannya, karena jika tidak selesai tepat waktu akan berakibat pada proses produksi lainnya dan proses pemasaran, dalam hal ini ketepatan waktu tersebut yang membentuk kemampuan disiplin siswa. Hal tersebut sesuai dengan teori Nur Cahyono (2015: 195), yang menyatakan bahwa aspek kesiapan kerja yang dibentuk melalui kegiatan prakerin adalah aspek kedisiplinan. Hasil wawancara narasumber guru yang menyatakan bahwa pola kedisiplinan di dunia industri sudah terjaga dan berfungsi untuk menjaga kualitas SDM sehingga siswa wajib mengikuti segala pola kedisiplinan yang diterapkan pada lingkungan industri.

Penguasaan kemampuan kerja sama siswa setelah melaksanakan kegiatan praktik kerja industri tergolong dalam kategori Sangat Baik. Hal tersebut dibuktikan dengan hasil analisis statistik deskriptif pada Tabel 7 . Berdasarkan tabel tersebut rata-rata nilai/skor kemampuan kerja sama adalah $82 \%$ dan jika diinterpretasikan melalui acuan dari Suharsimi Arikunto dalam Natsir Hendra (2011 :53), maka kemampuan kerja sama tersebut tergolong kedalam kategori Sangat Baik. Data nilai/skor yang lebih detail/rinci atau untuk melihat presentase jumlah siswa dan kategori nilai/skor tersebut dapat dilihat pada Gambar 5.

Tabel 7. Statistik Deskriptif Kerja Sama

\begin{tabular}{lc}
\hline \multicolumn{1}{c}{ Deskripsi Data } & Nilai \\
\hline Jumlah (N) & 76 \\
Mean & 82 \\
Median & 81 \\
Modus & 94 \\
Std. Deviasi & 10,41 \\
Skor Maksimum & 100 \\
Skor Minimum & 56 \\
\hline
\end{tabular}

Berdasarkan data Tabel 7 dapat dilihat bahwa kemampuan kerja sama siswa kelas XII teknik pemesinan SMK N 3 Yogyakarta setelah melaksanakan prakerin tergolong dalam kategori sangat baik 49\% , baik 49\%, dan cukup $2 \%$.

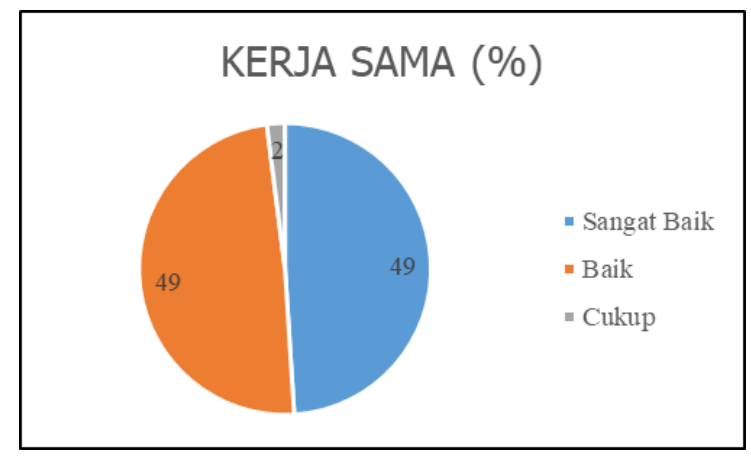

Gambar 5. Persentase Nilai Kerja Sama Siswa

Melihat dari analisis indikator/faktorfaktor pembentuk kemampuan kerja sama dan diinterpretasikan dengan acuan dari Suharsimi 
Arikunto dalam Natsir Hendra (2011: 53) pada Tabel 1, maka didapatkan hasil pada Gambar 6. Berdasarkan hasil analisis skor/nilai indikator kemampuan kerja sama siswa kelas XII teknik pemesinan SMK N 3 Yogyakarta melalui praktik kerja industri dapat diketahui nilai/skor tertinggi tertinggi terletak pada indikator nomor 1,5 , dan 9 yaitu saling keterbukaan terhadap tim, memiliki kepercayaan terhadap tim, dan tidak mendiskriminasi di dalam tim dengan nilai/skor sama yaitu $86 \%$ dan tergolong kategori Sangat Baik. Nilai/skor terendah terletak pada indikator nomor 6 yaitu Menyelesaikan Masalah Bersama Tim dengan nilai $78 \%$.

Tabel 8. Indikator Kemampuan Kerja Sama

\begin{tabular}{|c|c|}
\hline $\begin{array}{l}\text { Nomor } \\
\text { Indikator }\end{array}$ & Nama Indikator \\
\hline 1 & Saling Keterbukaan \\
\hline 2 & Saling Memahami \\
\hline 3 & Adanya Pembagian Tugas \\
\hline 4 & $\begin{array}{l}\text { Kesadaran Memiliki Suatu } \\
\text { Tim }\end{array}$ \\
\hline 5 & $\begin{array}{ll}\text { Memiliki } & \text { Kepercayaan } \\
\text { Terhadap Tim } & \end{array}$ \\
\hline 6 & $\begin{array}{l}\text { Menyelesaikan Permasalahan } \\
\text { Bersama Tim }\end{array}$ \\
\hline 7 & $\begin{array}{l}\text { Memiliki Rasa Tanggung } \\
\text { Jawab dengan Tim }\end{array}$ \\
\hline 8 & Saling Berkontribusi \\
\hline 9 & $\begin{array}{l}\text { Tidak Mendiskriminasi di } \\
\text { dalam Tim }\end{array}$ \\
\hline
\end{tabular}

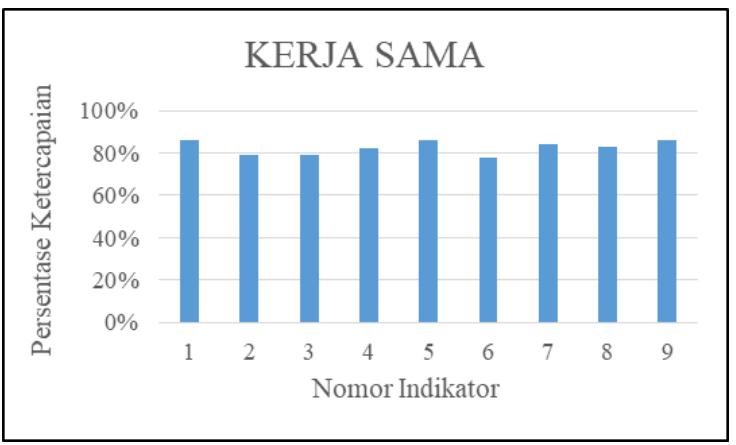

Gambar 6. Analisis Indikator Kerja Sama

Berdasarkan uraian tersebut dapat disimpulkan kemampuan kerja sama siswa kelas XII teknik pemesinan SMK N 3 Yogyakarta setelah praktik kerja industri tergolong sangat baik. Hal tersebut dikarenakan semua faktor-faktor/indikator pembentuk kerja sama dijalankan dengan baik/efektif saat kegiatan prakerin. Hasil wawancara siswa menyatakan bahwa kerja sama dapat dibentuk melalui kegiatan prakerin karena sangat mustahil seluruh pekerjaan disuatu industri tersebut dikerjakan secara individual sehingga siswa dituntut untuk melakukan kerja sama baik kepada karyawan maupun kepada unit/lini/bagian lain dari suatu industri tersebut. Hasil wawancara dari narasumber guru menyatakan pola kerja sama yang dilakukan oleh karyawan pada suatu industri akan dianggap oleh siswa sebagai sesuatu yang berpengalaman sehingga siswa memiliki kepercayaan untuk melakukan/menerapkan kemampuan kerja sama tersebut ke dalam suatu tim/kelompok di industri. Hal tersebut sejalan dengan teori dari Dina (2013: 13), yang menyatakan bahwa bentuk kerja sama dalam kepada karyawan dalam industri tersebut adalah memiliki kepercayaan kepada suatu tim, sehingga dengan begitu siswa lebih percaya diri untuk melakukan kerja sama kepada karyawankaryawan di industri saat prakerin. Siswa juga percaya dengan pola kerja sama yang dilakukan oleh karyawan di industri dan menganggap pola kerja sama tersebut lebih efektif/baik, sehingga siswa akan menerapkan pola-pola kerja sama tersebut kepada karyawan maupun kepada tim/kelompok.

Berdasarkan nilai praktik kerja industri siswa teknik pemesinan SMK N 3 Yogyakarta, maka nilai/skor rata-rata dari praktik kerja industri tergolong ke dalam kategori sangat baik. Nilai/skor rata-rata praktik kerja industri siswa berdasarkan analisis statistik deskriptif pada Tabel 9 adalah 83\%. Data nilai/skor yang lebih detail/rinci atau untuk melihat presentase jumlah siswa dan kategori nilai/skor tersebut dapat dilihat pada Gambar 6. Berdasarkan data dari gambar pie chart tersebut dapat dilihat bahwa nilai praktik kerja industri siswa kelas XII teknik pemesinan SMK N 3 Yogyakarta tergolong dalam kategori sangat baik dan baik 
dengan persentase siswa sangat baik 66\% dan baik 34\%.

Tabel 9. Statistik Deskriptif Nilai Prakerin

\begin{tabular}{lc}
\hline \multicolumn{1}{c}{ Deskripsi Data } & Nilai \\
\hline Jumlah (N) & 76 \\
Mean & 83 \\
Median & 83 \\
Modus & 85 \\
Std. Deviasi & 3,882 \\
Skor Maksimum & 90 \\
Skor Minimum & 75 \\
\hline
\end{tabular}

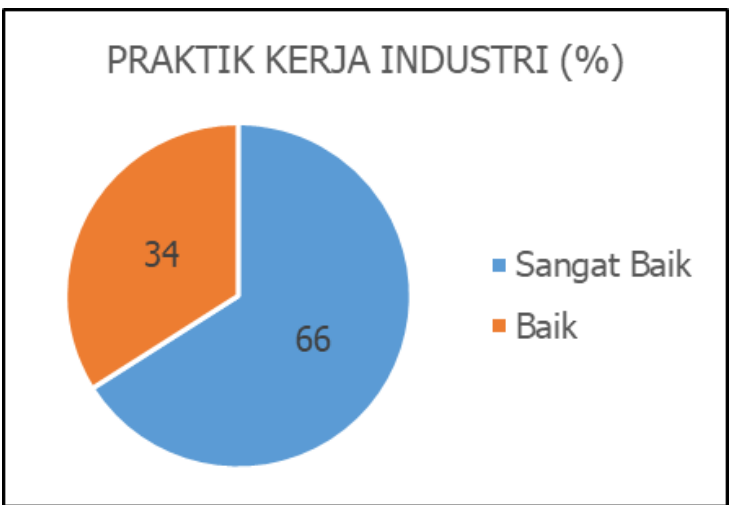

Gambar 7. Persentase Nilai Prakerin

Ketuntasan nilai Prakerin sesuai dengan buku Pedoman Praktik Kerja Industri SMK N 3 Yogyakarta (2019: 3). Berdasarkan data tabel tersebut semua siswa mendapat nilai $\geq 75$. Artinya semua siswa yang telah melaksanakan kegiatan praktik kerja industri mendapat nilai dengan kategori Tuntas. Pelaksanaan praktik kerja industri juga dianalisis berdasarkan nilai kemudian diinterpretasikan sesuai dengan Tabel 2 yang diambil dari Pedoman Praktik Kerja Industri SMK N 3 Yogyakarta (2019: 3). Hasil dari interpretasi pelaksanaan tersebut dapat dilihat pada Gambar 8. Berdasarkan gambar diagram tersebut dapat dinyatakan bahwa 26\% siswa mampu menyelesaikan $\geq$ $75 \%$ pekerjaan saat prakerin dan termasuk kategori sangat baik/sangat efektif, 54\% siswa mampu menyelesaikan $\geq 50 \%$ pekerjaan saat prakerin dan termasuk kategori baik/efektif, sedangkan 20\% siswa mampu menyelesaikan $\geq 25 \%$ pekerjaan saat prakerin dan termasuk kategori cukup. Berdasarkan interpretasi tersebut artinya bisa dinyatakan sebagian besar siswa melaksanakan kegiatan praktik kerja industri bidang manufaktur secara baik/efektif. Berdasarkan interpretasi tersebut artinya bisa dinyatakan sebagian besar siswa melaksanakan kegiatan praktik kerja industri bidang manufaktur secara baik/efektif.

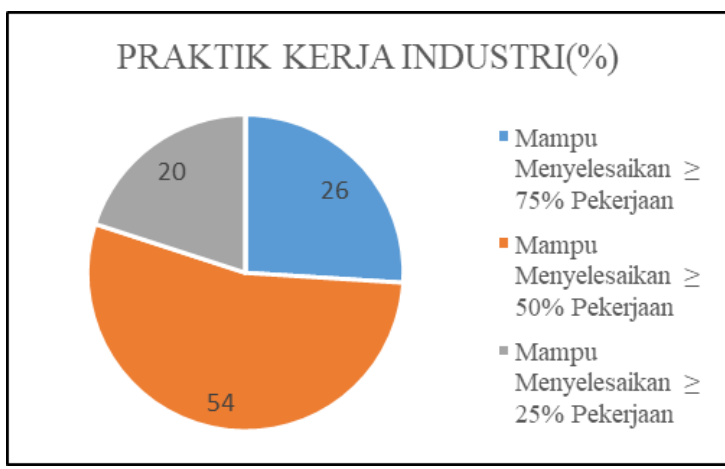

Gambar 8. Interpretasi Pelaksanaan Prakerin

Berdasarkan uraian tersebut maka pelaksanaan praktik kerja industri bidang manufaktur oleh siswa kelas XII teknik pemesinan SMK N 3 Yogyakarta berjalan secara baik/efektif. Efektifnya pelaksanaan praktik kerja industri diperoleh dengan mengintegrasikan kemampuan softskills seperti komunikasi, disiplin, kerja sama siswa dan sebagainya, sehingga ketika prakerin siswa mengetahui tujuan-tujuan yang akan dicapai dan output dari prakerin dapat tercapai. Hal tersebut juga sejalan dengan teori dari penelitian Putut Hargiyarto (2010: 113), bahwa dengan diintegrasikannya kemampuan softskills dalam prakerin maka peran strategis seperti link and match dapat tercapai. Efektifnya pelaksanaan praktik kerja industri diikuti dengan tingginya kemampuan komunikasi, disiplin, dan kerja sama siswa, dimana indikator-indikator kemampuan tersebut yang telah disusun dan disesuaikan dengan kondisi prakerin dilaksanakan sebagian besar dengan baik, maka dari itu dapat dikatakan bahwa pelaksanaan praktik kerja industri tersebut ikut serta atau memiliki peran dalam pembentukan kemampuan-kemampuan komunikasi, disiplin, dan kerja sama siswa. Hal tersebut sesuai dengan kajian teori dari penelitian Adriyati (2013: 10) bahwa mental 
dan motivasi siswa SMK sebagai tenaga kerja yang yang tergabung dalam soft skill dapat dibentuk melalui kegiatan praktik kerja industri.

Hasil wawancara siswa terkait pembentukan softskills melalui praktik kerja industri menyatakan, bahwa job/pekerjaan/produk yang di produksi tidak hanya melihat dari sisi kualitas atau hardskills tetapi dalam sisi ketepatan waktu produksi (disiplin). Siswa juga harus ikut serta dalam memecahkan berbagai permasalahan yang ada di industri tersebut, siswa juga terkadang dituntut untuk mengetahui bagaimana cara berinteraksi dengan kosumen agar produkproduk dapat dipasarkan. Hal tersebut jika dikaitkan dengan teori maka hal tersebut sesuai dengan teori penelitian dari Siti Mariah dan Machmud Sugandi (2010: 15) bahwa kegiatan praktik kerja industri adalah salah satu metode untuk mengembangkan kemampuan softskills siswa sejak dini. Akan tetapi dalam pelaksanaan praktik kerja industri masih terdapat hambatan yang perlu diperbaiki. Hasil wawancara narasumber guru menyatakan bahwa masih ada ketidaksesuaian tugas/job/tuntutan kemampuan yang diberikan kepada siswa baik dari SMK maupun dari industri. Salah satu contoh ketidaksesuaian tersebut terdapat pada Pedoman Praktik Kerja Industri SMK N 3 Yogyakarta (2019: 2) dimana indikator komunikasi tidak diikutsertakan dalam penilaian praktik kerja industri, sehingga pada kemampuan komunikasi masih terdapat indikator/faktor pembentuk komunikasi yang belum terbentuk secara baik, oleh karena itu pihak SMK dan industri diharapkan bisa lebih memperhatikan input dan output yang terdapat pada kegiatan praktik kerja industri.

Berdasarkan uraian tersebut dapat disimpulkan sebagian besar siswa kelas XII teknik pemesinan SMK N 3 Yogyakarta melaksanaan praktik kerja industri bidang manufaktur secara baik/efektif. Efektifnya pelaksanaan prakerin juga diikuti dengan tingginya kemampuan komunikasi, disiplin, dan kerja sama. Hal tersebut menandakan bahwa kemampuan-kemampuan tersebut dapat dibentuk melalui kegiatan prakerin. Akan tetapi masih terdapat hambatan seperti ketidaksesuaian tugas/job/tuntutan yang diberikan kepada siswa baik dari SMK maupun industri yang mengakibatkan beberapa indikator/faktor pembentuk kemampuankemampuan softskills tersebut belum berjalan secara maksimal.

\section{SIMPULAN}

Kemampuan komunikasi siswa kelas XII teknik pemesinan SMK N 3 Yogyakarta setelah melaksanakan kegiatan praktik kerja industri bidang manufaktur tergolong dalam kategori baik dengan nilai/skor rata-rata $78 \%$. Kemampuan disiplin siswa kelas XII teknik pemesinan SMK N 3 Yogyakarta setelah melaksanakan kegiatan praktik kerja industri bidang manufaktur tergolong dalam kategori sangat tinggi dengan nilai/skor rata-rata $85 \%$. Kemampuan kerja sama siswa kelas XII teknik pemesinan SMK N 3 Yogyakarta setelah melaksanakan kegiatan praktik kerja industri bidang manufaktur tergolong dalam kategori sangat tinggi dengan nilai/skor rata-rata $82 \%$. Pelaksanaan praktik kerja industri bidang manufaktur oleh siswa kelas XII teknik pemesinan SMK N 3 Yogyakarta berjalan secara baik/efektif dengan nilai/skor rata-rata 83\%. Efektifnya pelaksanaan prakerin juga diikuti dengan tingginya kemampuan komunikasi, disiplin, dan kerja sama. Hal tersebut menandakan bahwa kemampuankemampuan tersebut dapat dibentuk melalui kegiatan prakerin.

\section{DAFTAR RUJUKAN}

Adriyati Porbaningsih. (2013). Pengaruh Kegiatan Praktik Kerja Industri Terhadap Kemampuan Penguasaan Soft Skill Siswa. Laporan Penelitian. UNS Surakarta. 
Ajeng Erfelina. (2017). Hubungan Antara Kesiapan Kerja Dengan Ketakutan Menghadapi Kegagalan Pada Siswa SMK N 1 Blora. Jurnal Empati. 1(6). Hlm 17-20.

Dina Rollana dan Lucy Anna. (2013). Analisis Hubungan Kerja Sama Tim Untuk Meningkatkan Efisiensi Kerja Pada PT Mitha Samudera Wijaya Medan. Jurnal Fakultas Ekonomi Universitas Sumatera Utara. 1(4). Hlm. 1-15.

Eko N.C. (2015). Praktik Kerja Industri dan Kontribusinya Terhadap Kesiapan Kerja Siswa Kelas XII SMK Negeri 1 Pati. Economic Education Analysis Journal. 1(4). Hlm. 194-202.

Livia Putri. (2018). Peranan Kerja Sama Tim dan Semangat Kerja Terhadap Kinerja Karyawan Zolid Agung Perkasa. Jurnal Manajemen dan Start-Up Bisnis. 4(3). Hlm 417-424.

Maya Sandra. (2020). Komunikasi Sosial di Era Revolusi Industri 4.0. Jurnal Research Fair Unisri 2019. 1(4). Hlm. 65-77.

Nadia P.A. (2018). Kesiapan Kerja Siswa Ditinjau dari Keterampilan dan Bimbingan Karir Pada Siswa Kelas XII Akuntansi di SMK N 6 Sukoharjo. Laporan Penelitian. Universitas Muhammadiyah Surakarta.

Natsir Hendra Pratama. (2011). Studi Kelayakan Sarana dan Prasarana Laboratorium Komputer. Laporan Penelitian. Universitas Negeri Yogyakarta.

Perkinson, L. I. 2005. Dicipline In The Extremes, Potentially Damaging To Behavioral Safety Processes. Profesional Safety, Academic Research Library Journal. 4(50). hlm 31-35.

Putut Hargiyarto. (2010). Kesesuaian Materi Kegiatan Industri Mitra dengan Kompetensi Keahlian Pada Prosgram Praktik Kerja Industri Mahasiswa Jurdiknik Mesin Fakultas Teknik
UNY. Jurnal Pendidikan Teknologi Kejuruan. 1(19). Hlm 61-79.

Putut Hargiyarto. (2010). Praktik Industri Sebagai Implementasi Integrasi Hardskill dan Softskill dalam Pendidikan Kejuruan. Prosiding, Seminar Nasional Pendidikan Karakter pada Pendidikan Kejuruan. Yogyakarta: FT UNY.

Siti Mariah dan Machmud Sugandi. (2010). Kesenjangan Soft Skills Lulusan SMK Dengan Kebutuhan Tenaga Kerja Di Industri. Jurnal Inovasi dan Perekayasa Pendidikan. 3(1). Hlm. 379-400.

Sri Siswati. (2019). Pengembangan Soft Skills Dalam Kurikulum Untuk Menghadapi Revolusi Industri 4.0. Jurnal Pendidikan. 2(17). Hlm. 264-273.

Sri Wiranti. (2012). Membangun Kerja Sama Tim. Jurnal STIE Semarang. 3(4). Hlm. 59-65.

Stevani. (2015). Pengaruh Praktik Kerja Industri dan Keterampilan Siswa Terhadap Kesiapan Memasuki Dunia Kerja Siswa Administrasi Perkantoran SMK N 3 Padang. Journal Economic and Economic Education. 2(3). Hlm. 184-193.

Sugiyono. 2010. Metode Penelitian Pendidikan. Bandung: Alfabeta.

Sugiyono. 2011. Metode Penelitian Kombinasi. Bandung: Alfabeta.

Suharsimi Arikunto. (2010). Prosedur Penelitian Suatu Pendekatan Praktek. Jakarta: Rineka Cipta.

Suroto dan Nguyen Tien Hung. (2018). Management of an Industry Standard Class In Vocational High School. Jurnal Pendidikan Teknologi dan Kejuruan Fakultas Teknik UNY. 1(24). hlm. 46-51.

Suryanto, D., Kamdi, W \& Sutrisno. 2013. Relevansi Soft Skill Yang Dibutuhkan Dunia Usaha/Industri Dengan Yang 
Dibelajarkan Di Sekolah Menengah Kejuruan. Jurnal Teknologi dan Kejuruan. 2 (36). Hlm. 107-118.

Tim Pelaksanaan Prakerin. (2019). Pedoman Praktik Kerja Industri Tahun 2019. Yogyakarta: SMK N 3 Yogyakarta.

Zamzam Z.F. (2012). Pengaruh Unit Produksi, Prakerin, dan Dukungan Keluarga
Terhadap Kesiapan Kerja Siswa SMK. Jurnal Pendidikan Vokasi 2012. 3(2). Hlm. 397-409. 